\title{
ATTITUDES OF TEACHERS IN THE ARAB SCHOOLS IN ISRAEL TOWARDS INTEGRATION OF STUDENTS WITH SPECIAL NEEDS
}

\section{INTRODUCTION}

Research studies have shown that the teachers' attitude towards the children with special needs, also children with learning difficulties, and their attitudes towards the integration of these children in their classes are factors critical to their success ${ }^{1}$. Hence, they are important in the learning processes and in the integration of students in general and students at-risk special.

Philosophies regarding the education of children with learning difficulties have changed over the past two decades and several countries have led in the effort to implement policies which foster the integration and, inclusion of these students into mainstream environments. The movement of inclusive education has gained momentum in recent years, a key element in the successful implementation of the policy is the views of the personnel who have the major responsibility for implementing it, that is teachers. It is argued that teachers' acceptance of the policy of inclusion is likely to affect their commitment to implementing $\mathrm{it}^{2}$.

The purpose of this paper is to review the literature on mainstream teachers' attitudes towards integration and, inclusion and to show the need of design research on attitudes of teachers in schools in Arab society in Israel towards the integration of students with special needs into regular classes.

\footnotetext{
${ }^{1}$ Ministry of Education, Book of Inclusion: Clarification of outlooks and their implementation in the process of inclusion, http://meyda.education.gov.il/files/MinhalPedagogy/sefer_internet.pdf.

${ }^{2}$ B. Norwich, The relationship between attitudes to the integration of children with special educational needs and wider socio-political views: a US-English comparison, „European Journal of Special Needs Education" 1994, no. 9, p. 91-106.
} 
Attitudes of teacher about children with disabilities and special needs and their inclusion in regular education classrooms have been internationally identified in many studies as a key factor in the implementation of inclusive education $^{3}$. Inclusion is a global trend in education that requires the involvement of and collaboration between educational professionals. While educational professionals agree that educational rights of children with disabilities and the principle of inclusion - that schools should provide for the needs of all the children in their communities, regardless of ability and disability ${ }^{4}$ - there remain significant barriers to achieving these ideals.

If we speak about special needs, we can see that special educational needs terminology has survived so long because it is very difficult to find an acceptable substitute and because it is embodied in legislation. There are areas where dispensing with 'special' may not be too difficult. Journals have been renamed; for example, from Remedial Education to Support for Learning. Most secondary schools changed the names of their SEN (or even Remedial) Departments to Learning (or Curriculum) Support. It is a pity that SENCOs could not have been given another name, such as learning support coordinator. In the meantime, the use of 'additional' or 'individual needs' is becoming more common. No doubt these terms too will also become discredited with time. In the adult field, the term learning difficulties and disabilities is widely used"s. B. Norwich has drawn an interesting distinction between individual needs, exceptional needs and common needs ${ }^{6}$ :

- individual needs arising from characteristics that unique to the child and different from all others;

- exceptional needs arising from characteristics shared by some (visual impairment, high musical abilities);

- common needs arising from characteristics shared by all (e.g. the emotional need to belong and to feel related).

It has been argued that the approaches developed as part of what is now often referred to as special needs education have, continued to create barriers to progress ${ }^{7}$. Furthermore, researchers who have reviewed the empirical basis

\footnotetext{
3 W. Nketsia, A cross-sectional study of pre-service teachers' views about disability and attitudes towards inclusive education, ,International Journal of Research Studies in Education”2017, no. 6.

${ }^{4}$ P. Foreman, (ed.), Inclusion in action (2nd ed.), Cengage, Sydney 2008.

${ }_{5}$ Mittler P., Working towards inclusive education: Social contexts, David Fulton Publishers, London 2012.

${ }^{6}$ B. Norwich, op. cit., p. 91-106.

7 L. Florian, K. Black-Hawkins, Exploring inclusive pedagogy, „British Educational Research Journal”, July 2010.
} 
of specialised methods for particular categories of children that there is little support for a separate special needs pedagogy ${ }^{8}$. It means, effective teaching is effective teaching for all students. It means, it has been suggested that what are seen as specialised pedagogies further marginalise and exclude children with difficulties ${ }^{9}$. However, while agreeing with this assertion, Davis and Florian conclude that this does not diminish the need for specialist expertise. At the same time, it has been argued that "the preoccupation with individualised responses that have been a feature of special needs education, continue to deflect attention away from the creation of forms of teaching that can reach out to all learners within a class and the establishment of school conditions that will encourage such developments" ${ }^{10}$. This may help to explain why integration efforts that are dependent upon importing practices from special education tend to foster the development of new, yet more subtle forms of segregation, albeit within mainstream settings. In some countries, recent years have seen the introduction of teaching assistants who work alongside class teachers and also help students categorized as having ${ }^{11}$. It has been found that often, teachers feel that they can no longer cope. At the same time, the requirement for individualized education plans in some European contexts has encouraged some school principals to feel that many children need additional support, thus creating budget problems within education systems ${ }^{12}$.

In some situations, the category 'special educational needs' has become a repository for various groups who suffer discrimination in society, such as those from minority backgrounds ${ }^{13}$. In this way, special education can be a means of hiding discrimination against some groups of children behind an seemingly innocent label, thus justifying their low attainment and, their need to separate educational arrangements.

School integration according to Ghergut involves the inclusion of student with special needs in learning activities and school participation, depending on

8 L. Florian, K. Black-Hawkins, op. cit.

9 A. Lewis, B. Norwich (eds.), Special teaching for special children: a pedagogy for inclusion?, Open University Press, Maidenhead 2005.

${ }^{10}$ M. Ainscow, Towards inclusive schooling, „British Journal of Special Education” 1997, vol. 24 (1), p. 3-6; M. Ainscow, A. Dyson, S. Weiner, From Exclusion to Inclusion: Ways of Responding in Schools to Students with Special Educational Need, CfBT Education Trust, Berkshire 2013.

${ }^{11}$ M. Balshaw, Help in the classroom (2nd edition), David Fulton, London 1999.

${ }^{12}$ G. Fulcher, Disabling policies? A comparative approach to education policy and disability, Falmer, London 1989; M. Ainscow, A. Dyson, op. cit.

${ }^{13}$ S.C. Trent, A.J. Artiles, C.S. Englert, From deficit thinking to social constructivism: a review of theory, research and practice in special education, „Review of Research in Education” 1998, no. 23, p. 277-307. 
the potential, alongside other children ${ }^{14}$. An interesting approach of the concept of integration is provided by the same author, which recalls what is not integration $^{15}$. According to Author integration does not mean to isolate children with special needs in special classes of the school, or keeping them isolated from the rest of the class. School duty is getting them involved in learning activities. Integration does not mean accepting children with special needs in mass scholls just for benefits, the goal of integration is training and support. Alois Ghergut as cited in Dănescua and Iordăchescua ${ }^{16}$ considers that from a psycho-pedagogical point of view, integration can be seen under a triple aspect: as an aim, as a process and as a result. As an aim, integration wants the realization of a concordance between requirements and manifestations, a subordination of the secondary aspects to those that serve the orientation (it is about developing motivation, stating the aspirations, the models that can facilitate adaptation and integration). The concrete elements of personality (assimilations, capacities, aptitudes, abilities) should be trained, stimulated, cultivated, followed, in order to facilitate the adaptation-integration. As a process, integration is dynamic and consists of an assembly of mechanisms, finish and complete the respective action. The levels of the processes of regulation and auto regulation in the system are in the psycho-pedagogies' attention for the analysis and projecting of the educational programs reported to the individuality of the students. Integration is correlated especially by the educational work and social life, the evolution of some phenomenon found under the influence of the socio-economical environment. The integration is also appreciated as a positive indicator of the educational activity.

Croll and Mores ${ }^{17}$ showed the relationship between the severity of the deficiency of the pupils and teacher attitude by appeare the fact that students with mild difficulties are more easily accepted when we compared to students with serious difficulties. Etenesh ${ }^{18}$ as cited in Cramaruc ${ }^{19}$ studied the relationship be-

${ }^{14}$ A. Gherguț, Psihopedagogia persoanelor cu cerințe speciale. Strategii de educație integrată [Pedagogy of persons with special needs. Strategies for integrated education], Polirom, Iași 2001.

15 A. Gherguţ, op. cit.

${ }^{16}$ E. Dănescu, D. Iordăchescu, The scholar integration of students with special needs-a regional approach, „Procedia-Social and Behavioral Sciences” 2012, vol. 33, p. 588-592.

17 P. Croll, D. Moses, Special Needs in the Primary School: One in Five?, Cassell. London 2000.

E. Dănescu, D. Iordăchescu, op. cit.

${ }_{18}$ A. Etenesh, Inclusion of Children With Disabilities (CWD): Situational Analysis of Ethiopia, Paper presented at International Special Education Congress, University of Manchester, Manchester 2000.

${ }^{19}$ N.N. Cramaruc, Dinamica integrării copilului cu dizabilităţi severe [The dynamics of the integration of children with severe disabilities], www.scoalaspecialapascani.ro/wp.../volum-simpozion-2012-corectata.pdf. 
tween teachers attitude and the severity of the disability, and showed that the attitude of rejection is stronger in the case of students with severe disabilities than in case of those with less severe impairments. Daunarummo ${ }^{20}$ research the perception towards integration of directors, teachers from special schools, and teachers from normal schools from New Jersey. Data were collected through focus group interviews. Participants responded that they would need support from the authorities, training and qualifications, teachers' collaboration with teachers from special schools. Sharma and Sokal ${ }^{21}$ investigated the relationship between Canadian teachers' classroom behavior and attitude, caring, and self-reported effectiveness towards inclusion. Researches have come to the conclusion that teachers who had a positive behavior in the classroom towards the students with deficiencies have recorded lower scores in attitude measurement scales and concern towards inclusion. In Romania, Bolea ${ }^{22}$ investigated teachers' opinion towards the integration of education and special education in Cluj. The results were taken from interviews taken directly from persons involved in integration: principals, teachers, speech therapists, special education teachers, support teachers. In this research taken into account: difficulties encountered in integrating, teachers training, curriculum and assessment. The results were: lack of communication between specialists, stereotypes regarding the success of the integration of students with learning difficulties, less in training teachers to work with students with special needs, lack of materials and conditions to facilitate activity, overloaded curriculum, overloaded classrooms ${ }^{23}$.

Elliot ${ }^{24}$ measured the relationship between attitudes of teacher toward the inclusion of children with mild to moderate mental disabilities in physical education settings and the amount of practice attempts performed and the levels of success attained by these students when we compared them to their peers with-

20 A. Daunarummo, Necessary supports for effective high school inclusion classrooms: perceptions of administrators, general education teachers and special education teachers, Doctoral dissertation, Seton Hall University, http://scholarship.shu.edu/cgi/viewcontent.cgi?article=2302\&context $=$ dissertations.

${ }^{21}$ U. Sharma, L. Sokal, Can teachers self-reported efficacy, concerns and attitudes toward inclusion scores predict their actual inclusive classroom practices?, „Australian Journal of Special Education" 2016, vol. 40 (1), p. 21-38.

22 A. Bolea, Școala românească. Școala incluzivă [The Romanian School. The Integrated School], „Anuarul Institutului de Istorie George Barițiu”, Series Humanistica 2007, p. 233-254.

${ }^{23} \mathrm{~N}$. Lupu, Teachers opinions towards the integration of students with special needs in mass education, Transilvania University of Brasov, Series VII, „Social Sciences, Law” 2017, no. 10(1).

${ }^{24} \mathrm{~S}$. Elliot, The effect of teachers' attitude towards inclusion on the practice and success levels of children with and without disabilities in physical education, „International Journal of Special Education" 2008, no 23(3), p. 48-55. 
out disabilities. The findings suggested a relationship between teacher attitude toward inclusion and teacher effectiveness. Teachers that they have a positive attitude toward inclusion provided all of their students more practice attempts, at a higher level of success. Groce agree that different cultures have different interpretations and complex system of beliefs and practices concerning children with special needs ${ }^{25}$. Models ${ }^{26}$ have been found to influence people to think that disabilities are caused by an evil placed on an individual from the gods, devil, evil spirits, ghosts and powers of sorcery as a result of offences this individual has committed. "They believe that disability is caused by witchcraft, evil spirits and ghosts or a curse or punishment from gods, juju or deity for one's wrongs ${ }^{27}$. These beliefs are dominant in sub-Saharan African countries" ${ }^{28}$. Also, studies from countries in Asian and Middle East regions such as Israel ${ }^{29}$, United Arab Emirate $^{30}$ and $\mathrm{Nepal}^{31}$ have indicated that disability is often defined as something fearful as retribution for sinful acts, curse for the handicapped child and his family or caused by God's will. They believe disability could be inherited by children and bad luck in family.

In tsis text $\mathrm{i}$ want to focus on the specifity of inclusive education in Arab schools in Israel. The Arab education system in general and the issue of caring for

${ }^{25}$ N.E. Groce, Disability in cross-cultural perspective: rethinking disability, „The Lancet” 1999, no. 354(9180), p. 756-757.

${ }^{26} \mathrm{~J}$. Agbenyega, The power of labelling discourse in the construction of disability in Ghana, 2003, http://www.aare.edu.au/03pap/agb03245.pdf; J. Anthony, Conceptualising disability in Ghana: Implications for EFA and inclusive education, „International Journal of Inclusive Education” 2011, vol. 15, p. 1073-1086.

${ }^{27}$ M. Avoke, Models of disability in the labelling and attitudinal discourse in Ghana, „Disability \& Society” 2002, no 17, http://dx.doi.org/10.1080/0968759022000039064 (2002). p. 769-777; J. Agbenyega, op. cit.; B.H. Botts, N.A. Owusu, The state of inclusive education in Ghana, West Africa, „Preventing School Failure: Alternative Education for Children and Youth” 2013, vol. 57, p. $135-143$.

${ }^{28}$ See example: J. Anthony, op. cit.; G. Dart, My eyes went wide open'-An evaluation of the special needs education awareness course at Molepolole College of Education Botswana, „British Journal of Special Education” 2006, no. 33, p. 130-138; E. Gaad, Cross-cultural perspectives on the effect of cultural attitudes towards inclusion for children with intellectual disabilities, „International Journal of Inclusive Education" 2004, no. 8(3), p. 311-328.

${ }^{29}$ V. Florian, S. Katz, The impact of cultural, ethnic, and national variables on attitudes towards the disabled in Israel: A Review, „International Journal of Intercultural Relations” 1983, no. 7, p. $167-179$.

${ }^{30}$ E. Gaad, Cross-cultural perspectives on the effect of cultural attitudes towards inclusion for children with intellectual disabilities, „International Journal of Inclusive Education” 2004, no. 8(3), p. 311-328.

${ }^{31}$ B.M. Dhungana, The lives of disabled women in Nepal: Vulnerability without suport, „Disability \& Society” 2006, vol. 21, http://dx.doi.org/10.1080/09687590500498051, p. 133-146. 
children with special needs in school are at huge gaps in comparison to the Jewish education system ${ }^{32}$. In the Arab sector, many children who require special education are integrated in regular or special education classes that do not address their disability and needs. Arab parents suffer from feelings of shame, are sensitive and fearful of other people's reactions to being parents of children with special needs. We say, that the attitudes toward people with special needs is negative. There are also cases in which Arab parents hide their children at home and do not let them be a part of the community because of shame.

In examining attitudes toward integration of students with special needs into the regular classrooms, female teachers have more positive views towards integrating students with learning disabilities with mild disturbances, compared with students with many difficulties. "This is partly due to teachers' challenges and sense of self-efficacy as a result of integrating students with learning disabilities into their classrooms" ${ }^{\prime \prime 3}$.

It is important to be aware of the unique characteristics of Arab society in Israel, and beyond that, the situation of the education system in the Arab sector the sense of children with special needs is influenced not only by the formal form of integration, but also by its real content, by its continuing suitability for their needs and by the actual support they receive in the integrated frameworks. This aspect has a decisive weight in the perception of integration in the Arab sector and its implementation.

The Arab education system in general and the issue of caring for children with special needs in school in particular are very large in relation to the Jewish education system ${ }^{34}$. In the Arab sector, many children who require special education are enrolled in regular or special education classes that do not match their needs.

Stereotypes about people with disabilities, who perceive themselves and are perceived by society as weak. Disabilities are often viewed as embarrassing, and this attitude influences not only the people with disabilities, but also their families, who refrain from assisting the disabled family member lest others associate the disability with the family member. Providing support to families of people with disabilities also helps improve their relationship and facilitates joint efforts to cope with the complex challenges they face. Whereas ideally people with disabilities should be treated as equals, in some cases they are treated with pity or humil-

\footnotetext{
32 State Comptroller, State Comptroller Office, Israel 1992; H. Lahav, The role of the family in coping with the crisis in the Arab education system, Shining Publishing, Jerusalem 1995.

33 T. Haiman, The integrated classroom: attitudes of teachers towards students with and without learning disabilities, „Dapim” 2004, no. 38, p. 152-165.

34 State Comptroller, op. cit.; H. Lahav, op. cit.
} 
iated. People with disabilities they said that therapeutic agencies, institutions, and local authorities they share these negative attitudes. This is reflected in a failure to provide information, as well as in the belief that because people with disabilities do not have a power base, there is no need to address and deal with their distress ${ }^{35}$.

The usual teachers' attitudes towards integrating students with special needs into the regular classroom constitute a very important factor in the success of the integration of the students. There is a need of design research on attitudes of teachers in schools in Arab society in Israel towards the integration of students with special needs into regular classes and a need to strengthen teachers' knowledge and activities in this area. The study must be discuss the skills that underlie teachers' attitudes towards the integration of students with special needs, and identify the skills perceived by teachers as a condition for the successful integration of the student into the regular classroom.

\section{REFERENCES}

Agbenyega J., The power of labelling discourse in the construction of disability in Ghana, 2003, http://www.aare.edu.au/03pap/agb03245.pdf.

Ainscow M., Towards inclusive schooling, „British Journal of Special Education” 1997, vol. 24(1).

Ainscow M., Dyson A., Weiner S. From Exclusion to Inclusion: Ways of Responding in Schools to Students with Special Educational Need, CfBT Education Trust, Berkshire 2013.

Anthony J., Conceptualising disability in Ghana: Implications for EFA and inclusive education, „International Journal of Inclusive Education” 2011, vol. 15.

Avramidis E., Norwich B., Teachers' attitudes towards integration/inclusion: A review of literature, „European Journal of Special Needs Education” 2002, no. 17.

Avoke M., Models of disability in the labelling and attitudinal discourse in Ghana, „Disability \& Society" 2002, no. 17, http://dx.doi.org/10.1080/0968759022000039064 (2002). Balshaw M., Help in the classroom (2nd edition), David Fulton, London 1999.

Bolea A., Școala românească. Școala incluzivă [The Romanian School. The Integrated School], „Anuarul Institutului de Istorie George Barițiu”, Series Humanistica, 2007.

Botts B.H., Owusu N.A., The state of inclusive education in Ghana, West Africa, „Preventing School Failure: Alternative Education for Children and Youth" 2013, vol. 57.

Cramaruc N.M., Dinamica integrării copilului cu dizabilităţi severe [The dynamics of the integration of children with severe disabilities], www.scoalaspecialapascani.ro/wp.../volum-simpozion-2012-corectata.pdf.

Croll P., Moses D., Special Needs in the Primary School: One in Five? Cassell, London 2000.

Dănescu E., Iordăchescu D., The scholar integration of students with special needs-a regional approach, „Procedia-Social and Behavioral Sciences” 2012, vol. 33.

35 A. Sandler-Loeff, Y. Shahak, People with disabilities in Arab society in Israel: An opportunity for social change, JDC Israel, the Unit for Disabiblities and Rehabilitation, 2006. 
Dart G., My eyes went wide open'-An evaluation of the special needs education awareness course at Molepolole College of Education Botswana, „British Journal of Special Education” 2006, no. 33 .

Daunarummo A., Necessary supports for effective high school inclusion classrooms: perceptions of administrators, general education teachers and special education teachers, Doctoral dissertation, Seton Hall University, http://scholarship.shu.edu/cgi/viewcontent.cgi?article=2302\&context=dissertations. Dhungana B. M., The lives of disabled women in Nepal: Vulnerability without suport, „Disability \& Society” 2006, vol. 21, http://dx.doi.org/10.1080/09687590500498051.

Elliot S., The effect of teachers' attitude towards inclusion on the practice and success levels of children with and without disabilities in physical education, „International Journal of Special Education" 2008, no. 23(3).

Etenesh A., Inclusion of Children With Disabilities (CWD): Situational Analysis of Ethiopia, Paper presented at International Special Education Congress, University of Manchester, Manchester 2000.

Florian V., Katz S., The impact of cultural, ethnic, and national variables on attitudes towards the disabled in Israel: A Review, „International Journal of Intercultural Relations” 1983, no. 7.

Florian L., Black-Hawkins K., Exploring inclusive pedagogy, „British Educational Research Journal" 2010.

Foreman P. (ed.), Inclusion in action (2nd ed.), Cengage, Sydney 2008.

Fulcher G., Disabling policies? A comparative approach to education policy and disability, Falmer, London 1989.

Gaad E., Cross-cultural perspectives on the effect of cultural attitudes towards inclusion for children with intellectual disabilities, „International Journal of Inclusive Education” 2004, no. 8(3).

Gherguț A., Psihopedagogia persoanelor cu cerințe speciale. Strategii de educație integrată [Pedagogy of persons with special needs. Strategies for integrated education], Polirom, Iași 2001.

Gherguț A., Psihopedagogia persoanelor cu cerinţe educative speciale. Strategii diferenţiate şi incluzive in educatie [Pedagogy of persons with special education needs. Differentiated and inclusive strategy in education], Polirom, Iaşi 2006.

Groce N. E., Disability in cross-cultural perspective: rethinking disability, „The Lancet” 1999, no. 354(9180).

Haiman T., The integrated classroom: attitudes of teachers towards students with and without learning disabilities, „Dapim” 2004, no. 38.

Karni-Weizer N., Reiter S., Teachers'Attitudes towards Integrating Students with Disabilities in Junior High Schools in the Arab Sector in Israel, „Issues in Special Education and Rehabilitation" 2010.

Lahav H., The role of the family in coping with the crisis in the Arab education system, Shining Publishing, Jerusalem 1995.

Lewis A., Norwich B., (eds.), Special teaching for special children: a pedagogy for inclusion?, Open University Press, Maidenhead 2005.

Lupu N., Teachers opinions towards the integration of students with special needs in mass education, Transilvania University of Brasov, Series VII, „Social Sciences, Law” 2017, no. 10(1).

Mittler P., Working towards inclusive education: Social contexts, David Fulton Publishers, London 2012. 
Norwich B., The relationship between attitudes to the integration of children with special educational needs and wider socio-political views: a US-English comparison, „European Journal of Special Needs Education" 1994, no. 9.

Norwich B. Special needs education or education for all: connective specialisation and ideological impurity, „British Journal of Special Education” 1996, no. 23(3).

Nketsia W., A cross-sectional study of pre-service teachers' views about disability and attitudes towards inclusive education, „International Journal of Research Studies in Education” 2017, no. 6 .

Ministry of Education, Book of Inclusion: Clarification of outlooks and their implementation in the process of inclusion, http://meyda.education.gov.il/files/MinhalPedagogy/sefer_internet.pdf.

Ronen H., The future of the Special Education School, „Issues in Special Education and Rehabilitation" 2003, no. 18.

Sandler-Loeff A., Shahak Y. People with disabilities in Arab society in Israel: An opportunity for social change, JDC Israel, the Unit for Disabiblities and Rehabilitation, 2006.

Sharma U., Sokal, L., Can teachers self-reported efficacy, concerns and attitudes toward inclusion scores predict their actual inclusive classroom practices?, „Australian Journal of Special Education" 2016, vol. 40(1).

State Comptroller, State Comptroller Office, Israel 1992.

Trent S.C., Artiles A.J., Englert, C.S., From deficit thinking to social constructivism: a review of theory, research and practice in special education, „Review of Research in Education” 1998, no. 23.

Zmero O., Kurtz C., Reiter S., Feelings of Loneliness, Self-esteem and Adaptation among Arab hearing impaired pupils, in partial and full integration settings/ ISER, „Issues in Special Education \& Rehabilitation" 2007.

\author{
Author: Enas Majadley \\ Title: Attitudes of teachers in the Arab schools in Israel towards integration of students with special \\ needs \\ Keywords: Integration in education, Attitudes of teachers, Special needs, Arab sector in Israel \\ Discipline: Pedagogics \\ Language: English \\ Document type: Article
}

\title{
Summary
}

The program for the integration of children with special needs in the regular educational frameworks supports and encourages the integration of children with a variety of special needs, temporary or ongoing, within the context of regular education, and sees integration as both a goal and value. The integration program is operated through a training and treatment system in the educational frameworks, which were formulated according to the special needs of those students. With the increase in the trend towards integration in Israel and the expectation that this trend will grow in the future, it is essential to continue to explore teachers' perceptions and attitudes regard- 
ing integration as well as their needs for training and continuing education. The Arab education system in general and the issue of caring for children with special needs in school, in particular, are at huge gaps. The purpose of this paper is to review the literature on mainstream teachers' attitudes towards integration and, more recently, inclusion and to show the need of design research on attitudes of teachers in schools in Arab society in Israel towards the integration of students with special needs into regular classes. 